\title{
IMPLEMENTASI METODE EXPERIENTIAL LEARNING DALAM PENGEMBANGAN SOFTSKILLS MAHASISWA YANG MENUNJANG INTEGRASI TEKNOLOGI, MANAJEMEN DAN BISNIS
}

\author{
Rahayu S. Purnami dan Rohayati \\ Universitas Pendidikan Indonesia \\ e-mail:rsripurnami@gmail.com ${ }^{l}$, rohayatiyadi@yahoo.co.id ${ }^{2}$
}

\begin{abstract}
ABSTRAK
Integrasi teknologi, manajemen dan bisnis yang menghasilkan produk yang unggul, inovatif dan kompetitif tidak hanya tergantung pada penguasaan hardskills para pelakunya, namun juga perlu penguasaan softskills termasuk bagi para mahasiswa. Pembekalan softskills bagi mahasiswa menjadi sangat penting supaya mereka tidak hanya memiliki kompetensi akademik dan profesionalitas (hardskills) saja, namun juga kemampuan intrapersonal dan interpersonal (softskills). Kemampuan intrapersonal meliputi kesadaran diri dan kemampuan diri. Sedangkan kemampuan interpersonal meliputi kesadaran sosial dan kemampuan sosial. Pembelajaran softskills mengantarkan peserta didik untuk mengalami perubahan perilaku secara perlahan-lahan sehingga mereka menjalankan, merasakan manfaat yang diperoleh hingga menjadi kebiasaan. Experiential learning merupakan sebuah proses pembelajaran dimana para pembelajar menggabungkan pengetahuan, keterampilan dan nilai melalui pengalaman-pengalaman langsung. Pembelajaran akan lebih optimal apabila para peserta dilibatkan. Ide dan prinsip-prinsip yang dialami dan ditemukan oleh para pembelajar akan lebih efektif dalam perubahan perilaku. Makalah ini memaparkan konsep pengembangan softskills dengan metode experiential learning dan peningkatan peran dosen sebagai fasilitator.
\end{abstract}

Kata Kunci: softskills, pengalaman pembelajaran, fasilitator

\section{ABSTRACT}

Integration of technology, management and business that produce superior products, innovative and competitive not only depend on the mastery hardskills the perpetrators, but also need to control softskills including for students. Softskills debriefing for students is very important that they not only have the academic competence and professionalism (hardskills), but also the ability of intrapersonal and interpersonal (softskills). Intrapersonal skills include self-awareness and ability. While interpersonal skills include social awareness and social skills. Learning softskills deliver students to experience behavior changes slowly so that they act and feel the benefits to become a habit. Experiential learning is a process of learning in which learners combine knowledge, skills and values through direct experiences. Learning would be optimal if the participants involved. Ideas and principles are experienced and discovered by the learners will be more effective in changing behavior. This paper describes the concept of development softskills experiential learning methods and increasing the role of teacher as facilitator.

Keywords: softskills, experiential learning, facilitator.

\section{PENDAHULUAN}

Permasalahan yang akan diangkat dalam makalah ini adalah mengenai implementasi metode Experiential Learning (EL) dalam pengembangan softskills mahasiswa yang menunjang integrasi teknologi, manajemen, dan bisnis. Masalah ini menarik untuk diangkat seiring dengan berkembangnya fenomena yang terjadi pada dunia kerja saat ini yang tidak hanya membutuhkan kompetensi akademik dan profesionalitas (hard skills) saja, namun juga kemampuan intrapersonal dan interpersonal (softskills). Softskills menjadi begitu penting karena banyak perusahaan tak hanya membutuhkan tenaga kerja yang pintar dan mampu mengerjakan tugas-tugas yang diberikan. Perusahaanperusahaan kini juga menginginkan tenaga kerja atau karyawan yang mampu berkomunikasi, bersosialisasi, pekerja keras, cerdas, beradaptasi dengan lingkungan kerja, serta memiliki kemampuan untuk bekerja sama dengan rekan kerja maupun atasan.

Majalah SWA No.11/XXVI/26Mei-9Juni 
2010 melakukan survei terhadap 100 profesional SDM level manajer ke atas dari berbagai bidang usaha mengenai kemampuan/ skill apa saja yang sebaiknya dimiliki oleh calon karyawan entry level yang akan direkrut, dan hasilnya berdasarkan urutan dari peringkat teratas adalah sebagai berikut komunikasi, kerjasama, kepemimpinan, komputer/office application, pemahaman global, kemampuan adaptasi, manajemen waktu, pemasaran, manajemen dan strong with ethic.

Kompas 16 Oktober 2012 melaporkan bahwa etika kerja tenaga kerja Indonesia menjadi persoalan serius bagi pengusaha dalam menjalankan bisnis di Indonesia. Laporan Forum Ekonomi Dunia (WEF) dalam the Global Competitiveness Report 2012-2013 melaporkan rendahnya etika kerja tenaga kerja Indonesia menduduki peringkat ke-4 dari 16 faktor yang menghambat bisnis di Indonesia pada 2011. Etika kerja menduduki peringkat ke-14 pada 2010 dan ke-11 pada 2009. Tiga faktor teratas yang menghambat bisnis pada 2009-2011 sama meski urutannya berbeda. Ketiga faktor itu adalah birokrasi pemerintah yang tidak efektif, korupsi, dan infrastruktur yang tidak memadai.

Pentingnya penguasaan softskills ketika memasuki dunia kerja menuntut lembaga pendidikan terutama pendidikan tinggi untuk menyiapkan para lulusannya memiliki softskills yang dibutuhkan di dunia kerja. Perlu dirancang program pengembangan softskills di perguruan tinggi sebagai sarana membangun etika kerja.

Meminjam istilah dalam reaksi kimia yang dikenal dengan reaksi cepat dan lambat, pengajaran softskills haruslah bersifat reaksi lambat, bukan reaksi cepat. Peserta diantarkan untuk mengalami perubahan perilaku secara perlahan-lahan sehingga mereka menjalankan, merasakan manfaat yang diperoleh hingga menjadi kebiasaan. Bukan perubahan radikal yang diiringi pemaksaan untuk segera berubah. Begitu juga yang terjadi dengan perubahan perilaku, apabila langsung dengan pemaksaan dan reaksi cepat, orang akan cenderung menolak terlebih dengan kebiasaan lamanya, dia sudah berada di wilayah nyamannya sudah cukup lama, apalagi kalau bertentangan dengan nilai-nilai yang sudah lama dia yakini.

Pembelajaran (learning) adalah setiap perubahan perilaku yang relatif permanen, terjadi sebagai hasil dari pengalaman. Definisi tersebut mengandung beberapa komponen yaitu pembelajaran melibatkan perubahan, perubahan harus bersifat jangka panjang bukan sementara, beberapa pengalaman diperlukan untuk pembelajaran. Apabila sebuah pengalaman menghasilkan sebuah perubahan yang relatif permanen dalam perilaku maka pembelajaran telah terjadi (Robbins, 2008).

John Dewey (1938) memperhatikan terdapat hubungan antara pendidikan dan pengalaman seseorang. Selanjutnya dia menyampaikan bahwa pendidikan secara keseluruhan terjadi berawal dari pengalaman. (Simmons, 2006) Para ahli EL sepakat bahwa pengalaman merupakan inti dari proses pembelajaran. Beard dan Wilson mendefinisikan EL sebagai sebuah proses keterikatan yang aktif antara diri seseorang dengan lingkungannya. Sedangkan David Kolb menyatakan EL sebagai sebuah proses dimana pengetahuan diperoleh dari transformasi pengalaman. Selanjutnya Lawler dan King menjelaskan proses pembelajaran pada usia dewasa meliputi prinsip-prinsip iklim pembelajaran yang penuh respek, mendorong partisipasi aktif para peserta, dibangun dari pengalaman, menggunakan kolaborasi yang dibutuhkan, belajar dengan bertindak, dan melibatkan para peserta. (Estepp et al. , 2012)

Makalah ini memaparkan konsep pengembangan softskills dengan metode experiential learning dan peningkatan peran dosen sebagai fasilitator. 


\section{Pengertian Softskills}

Softkills merupakan keterampilan dan kecakapan hidup, baik dengan diri sendiri, berkelompok atau bermasyarakat serta dengan Sang Pencipta. (Elfindri et al., 2010) Secara garis besar softskills merupakan gabungan kemampuan intrapersonal dan kemampuan interpersonal.

Kemampuan intrapersonal meliputi kesadaran diri atau self awareness (mencakup kepercayaan diri, penilaian diri, sifat dan preferensi, serta kesadaran emosional), serta kemampuan diri atau self skill (perkembangan diri, pengendalian diri, kepercayaan, kekhawatiran, manajemen waktu, proaktivitas, dan hati nurani). Sementara itu, kemampuan interpersonal meliputi kesadaran sosial atau social awareness (kesadaran politik, mengembangkan orang lain, memanfaatkan keragaman, orientasi pelayanan, dan empati) dan kemampuan sosial atau social skill (kemampuan kepemimpinan, pengaruh, komunikasi, manajemen konflik, kerjasama, sinergi dan kemampuan berorganisasi). (Goleman, 2005)

Pengertian softskills seperti yang dimuat pada wikipedia.com 2011 "Soft skills is a sociological term relating to a person's "EQ" (Emotional Intelligence Quotient), the cluster of personality traits, social graces, communication, language, personal habits, friendliness, and optimism that characterize relationships with other people. Soft skills complement hard skills (part of a person's $I Q)$, which are the occupational requirements of a job and many other activities." Softskills adalah sebuah istilah kemasyarakatan atau sosiologi untuk menunjukkan tingkat EQ seseorang, yang terdiri dari kelompok sifat kepribadian, diterima oleh masyarakat, komunikasi, bahasa, kebiasaan seseorang, keramahan, dan optimisme yang mencirikan hubungan dengan orang lain. Soft Skills merupakan komplemen dari hardskills (IQ seseorang) yang merupakan syarat dari sebuah pekerjaan.

\section{Pengertian Experiential Learning (EL)}

Experiential Learning berdasar pada sebuah premis bahwa pengalaman merupakan dasar dari seluruh pembelajaran. Sebagian besar teori dan praktek EL mengacu pada konsep yang disampaikan John Dewey pada awal abad 20. Dewey menyampaikan "I assume that amid all uncertainties there is one permanent frame of reference: namely, the organic connection between education and personal experience” (Myers, 2004)

David Kolb (1984) menyampaikan model proses EL yang berupa proses yang melingkar dan terdiri dari empat fase. Fase Concrete Experience menggunakan pengalaman

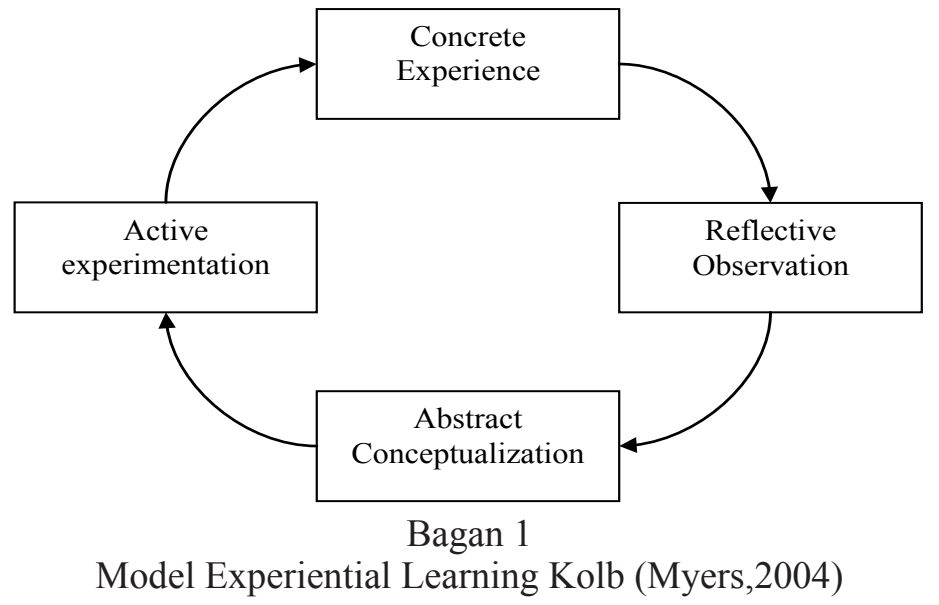

yang sudah dilalui peserta atau pengalaman yang disediakan untuk pembelajaran yang lebih lanjut. Fase Reflective Observation mendiskusikan pengalaman para peserta yang telah dilalui atau saling berbagi reaksi dan observasi yang telah dilalui. Fase Abstract Conceptualization proses menemukan tren yang umum dan kebenaran dalam 
pengalamanyang telah dilalui peserta atau membentuk reaksi pada pengalaman yang baru menjadi sebuah kesimpulan atau konsep yang baru. Fase Active Experimentation modifikasi perilaku lama dan mempraktikkan pada situasi keseharian para peserta.

Association for Experiential Education (AEE) mendefinisikan "experiential education is a process through which a learner construct knowledge, skill, and value from direct experiences." Pendidikan berbasis pengalaman merupakan sebuah proses dimana para pembelajar membangun pengetahuan, keterampilan dan nilai dari pengalaman langsung.

Metode Experiential Learning didasari beberapa keyakinan:

- Para pembelajar belajar yang terbaik adalah ketika mereka dilibatkan dalam pengalaman-pengalaman pembelajaran.

- Ide dan prinsip yang dialami dan ditemukan oleh pembelajar akan lebih

Tabel 1

Perbedaan antara experiential learning dan content based learning

\begin{tabular}{|l|l|}
\hline \multicolumn{1}{|c|}{ Experiential Learning } & \multicolumn{1}{c|}{\begin{tabular}{c}
\multicolumn{1}{c|}{ Content-Based } \\
Learning
\end{tabular}} \\
\hline - Aktif & - Pasif \\
- Berdasar pada penemuan sendiri & - Berdasar pada pendapat ahli \\
- Partisipatif, dari berbagai arah & - Autokratik, satu arah \\
- Belajar dengan melakukan & - Belajar dengan mendengarkan \\
- Keseimbangan & - Terstruktur \\
- Akhir yang terbuka (open-ended) & - Cakupannya telah ditentukan \\
- Didorong untuk menemukan & - Fokus pada tujuan pembelajaran yang \\
\hline
\end{tabular}

Diadaptasi dari Ng, 1997

efektif dalam perubahan perilaku.

- Terdapat perbedaan gaya pembelajaran yang disukai dari masing-masing individu.

- Komitmen para pembelajar dalam belajar akan lebih besar bila mereka turut terlibat pada proses pembelajaran mereka sendiri.

- Pembelajaran terjadi melalui proses pengalaman yang kongkret (concrete experience), observasi reflektif (reflective observation), konseptualisasi abstrak (abstract conceptualisation) dan eksperimentasi aktif (active experimentation).

- Perilaku pembelajaran akan mempengaruhi keyakinan seseorang. $(\mathrm{Ng}, 1997)$

\section{Karakteristik Pembelajaran pada Orang Dewasa dan Experiential Learning}

Setiap proses pembelajaran selalu melibatkan tiga dimensi, yaitu dimensi konten, insentif, dan sosial. dimensi konten atau ini meliputi pengetahuan, pemahaman, keterampilan, kemampuan, sikap dan kesukaan. Dimensi insentif meliputi emosi, perasaan, motivasi, kemauan atau kehendak. Dimensi sosial meliputi interaksi, komunikasi, dan kerjasama. (Illeris, 2007)

Malcolm Knowles (1984) menyampaikan teori pembelajaran bagi orang dewasa yang disebut andragogi. Prinsip pembelajaran bagi orang dewasa menurut Knowles antara lain: (1) Orang dewasa sebaiknya diikutsertakan dalam perencanaan dan pengaturan instruksi mereka sendiri. EL dapat mencapai hal ini melalui fase-fase observasi reflektif (reflective observation), konseptualisasi abstrak (abstract conceptualisation) dan eksperimentasi aktif (active experimentation); (2) Pengalaman penting dalam pengajaran orang dewasa. Fase pengalaman yang kongkret (concrete experience) dan eksperimentasi aktif (active 
experimentation) menyajikan pengalaman bagi para pembelajar; (3) Orang dewasa lebih peduli pada bahan ajar yang secara langsung dan segera berhubungan dengan dirinya. EL dapat mencapai hal ini jika para instruktur atau fasilitator menemukan karakteristik dan kebutuhan para pembelajar yang akan mengikuti proses pembelajaran; (4) Orang dewasa lebih menyukai pembelajaran dengan pendekatan penyelesaian masalah (problem solving) daripada pendekatan yang berdasarkan pada konten (contentbase). Pendekatan yang berfokus pada penyelesaian masalah (problem solving) menghadirkan pengalaman-pengalaman atau situasi-situasi yang para peserta butuhkan dalam pekerjaan untuk diselesaikan. Dengan memberikan pengalaman yang konkret pada para pembelajar dengan fenomena yang sedang dipelajari, EL dapat dengan mudah digunakan untuk mengembangkan lingkungan pembelajaran yang problembased. ( Myers, 2004)

Implementasi Experiential Learning dalam Pembelajaran Softskills

Experiential Learning dapat efektif apabila dilaksanakan dengan memperhatikan hal-hal sebagai berikut:

- 'Ice breaking' di awal pembelajaran untuk membangkitkan semangat para peserta

- Mengembangkan atmosfer pembelajaran yang kondusif dan suportif.

- Memperkenalkan kegembiraan dalam pengerjaan tugas pembelajaran.

- Mendorong berfikir kreatif.

- Membantu para peserta melihat dari

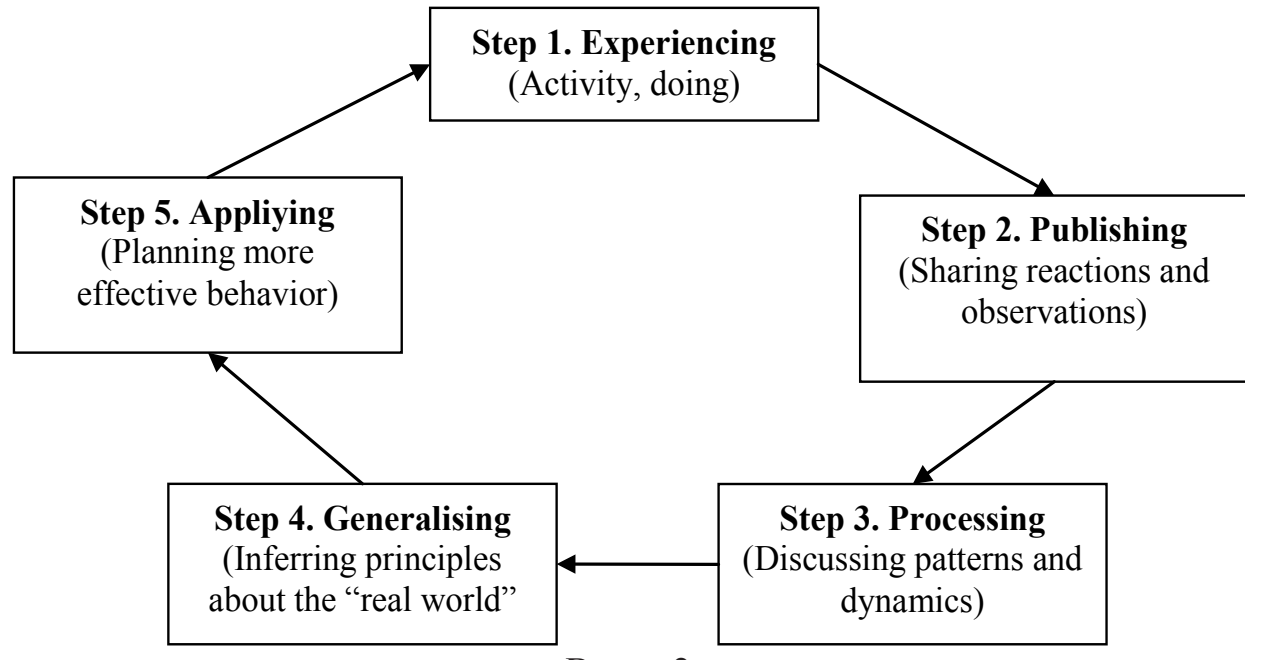

Bagan 2

The Framework for Facilitation (Boon,1997)

perspektif yang berbeda

- Meningkatkan kesadaran akan perlunya berubah.

- Meningkatkan kesadaran diri. ( Ng, 1997)

Implementasi EL dalam pembelajaran softskills di Perguruan Tinggi akan efektif apabila dosen bertindak sebagai seorang fasilitator. Fasilitator merupakan sebuah proses membimbing, seseorang yang membuat sebuah proses menjadi lebih mudah atau lebih sesuai. Fasilitator merupakan seorang pengorganisir dan komunikator dengan keahlian khusus pada dinamika kelompok. Mereka memastikan berlangsungnya keterlibatan dua arah yang menekankan pada proses mendengar aktif sebagaimana komunikasi yang terpercaya diantara para peserta. Peran para fasilitator adalah mengatur struktur dan isi dari pertemuan. Struktur merupakan 'how?' bagaimana proses yang 
terjadi pada pertemuan tersebut seperti agenda, bagaimana pengambilan keputusan, bagaimana penggunaan sarana pengambilan keputusan. Sedangkan isi atau konten merupakan 'what?' yang terdiri dari subyek dari pertemuan tersebut, permasalahan, analisis dan rekomendasi. (Boon,1997)

\section{Penggunaan Softpower bagi para Dosen}

Faktor yang sangat penting dalam keberhasilan pembelajaran ini adalah peran dosen sebagai fasilitator. Peran sebagai fasilitator memiliki pengertian mempermudah, membantu para peserta didik untuk belajar melalui apa yang dialaminya. Para dosen sebaiknya menggunakan softpower daripada hardpower dalam menjalankan perannya.

Konsep dasar power (kekuasaan) adalah kemampuan untuk mempengaruhi pihak lain untuk memperoleh tujuan yang diinginkan. Terdapat tiga jalan besar untuk melakukannya yaitu yang pertama dengan ancaman disertai kekerasan atau sering disebut dengan pemberian "sticks", yang kedua dengan memberi imbalan atau "carrots" dan yang ketiga yaitu mempengaruhi mereka atau memberikan mereka pilihan, sehingga mereka menginginkan apa yang Anda mau. Jika anda bisa membuat mereka tertarik menginginkan apa yang anda mau (dengan membantu menentukan pilihan atau preferensi). Hal ini jauh lebih murah dibandingkan dengan metode "sticks \& carrots".

Softpower adalah kemampuan untuk membuat pihak lain menjalankan apa yang kita inginkan tanpa kita harus menggunakan kekerasan atau membayar melalui daya tarik (Soft Power is the ability to obtain what you want through co-option and attraction rather than the hardpower of coercion and payment). Pengertian ini dikembangkan oleh Joseph Nye seorang profesor dari Harvard University yang pada awalnya menggunakan teori ini untuk hubungan internasional maupun militer.
Sedangkan hardpower awalnya merupakan istilah dalam hubungan internasional, merupakan teori yang menjelaskan penggunaan kekuatan militer dan sangsi ekonomi untuk mempengaruhi perilaku dan minat lawan politik. Hal ini bertolak belakang dengan softpower yang artinya power yang berasal dari diplomasi, budaya dan sejarah.

Pada tahun 2008, Nye menggunakan konsep hard and soft power pada kepemimpinan individu dalam "the Powers to lead." Di level individu, contoh kunci dari sumber soft power yaitu karisma, komunikasi, persuasi, tindakan simbolis, dan tindak tanduk yang patut dicontoh. Berbeda dengan hardpower, seperti kekuatan militer, dalam softpower pihak lain melakukan apa yang kita inginkan karena keinginan dari dirinya sendiri berkat kemampuan non kekerasan yang kita miliki.

Beberapa cara menumbuhkan untuk menumbuhkan softpower dapat ditempuh dengan cara:

- Kenali diri sendiri dan orang lain

- Memahami terlebih dahulu, baru kemudian dipahami

- Memimpin dengan contoh

- Konsistensi dalam bertindak

- Fleksibilitas dalam berkomunikasi

- Menghimbau dengan motif mulia

- Meningkatkan saldo Rekening Bank Emosi kepada pihak lain

- Senantiasa kreatif dan sabar

\section{KESIMPULAN}

Dari pemaparan di atas, dapat ditarik beberapa kesimpulan mengenai implementasi metode EL dalam pengembangan softskills mahasiswa yang menunjang integrasi teknologi, manajemen dan bisnis.

Yang pertama, pengembangan softskills bagi mahasiswa sangat penting sebagai 
bekal ketika memasuki dunia kerja dan memperbaiki etika kerja.

Yang kedua, metode EL sangat sesuai diterapkan pada usia dewasa termasuk bagi mahasiswa yang telah memasuki usia dewasa. Sehingga pengembangan softskills bagi mahasiswa sangat sesuai diterapkan dengan menggunakan metode EL ini.

Yang ketiga, peran dosen dalam pengembangan softskills dengan metode EL ini adalah sebagai fasilitator yang mempermudah, membantu para peserta didik untuk belajar melalui apa yang dialaminya. Penggunaan softpower bagi para dosen akan lebih efektif bila dibandingkan dengan menggunakan hardpower.

Pengembangan softskills bagi para mahasiswa saat ini telah menjadi fokus di beberapa perguruan tinggi oleh karena itu penulis memberikan beberapa saran untuk pengembangan dan pengkajian lebih lanjut mengenai pengembangan softskills di perguruan tinggi.

Yang pertama, pengembangan softskills harus menyeluruh baik pemilihan metode pembelajaran, penyiapan materi yang sesuai dengan kebutuhan dunia kerja, penyiapan sarana pembelajaran, penguasaan dosen sebagai fasilitator hingga evaluasi berkala efektivitas pembelajaran baik dari mahasiswa, dosen, dan para pemangku kepentingan yang lain seperti dunia industri dan orang tua.

Yang kedua, kajian teoritis mengenai pengembangan softskills bagi mahasiswa dengan menggunakan metode EL dapat dilanjutkan dengan penelitian empiris untuk menguji teori-teori yang ada.

\section{DAFTAR PUSTAKA}

Boon, C. C. S. 1997. The Craft of Facilitation. Conference Proceedings Asia Pasific Conference \& Exhibition on Experiential Learning'97

Elfindri et al. 2010. Softskills untuk pendidik. Baduose Media

Estepp, Ch. M et al. 2012. An Experiential Learning Model of Faculty Development to Improve Teaching, NACTA Journal, vol 56, p 79-86

Goleman, D. 2005. Kecerdasan Emosi untuk Mencapai Puncak Prestasi. Jakarta:Gramedia Pustaka Media

Illeris, K. 2007. What do We Actually Mean by Experiential Learning?, Human Resource Development Review, vol 6, p 84-95

Myers, B. E. dan T Grady R. 2004. Conducting and Evaluating Professional Development Workshops using Experiential Learning. NACTA Journal, vol 48, p 27-32

Proudman, B. 1997. Experiential Corporate Training:Working with the Whole Person. Conference Proceedings Asia Pasific Conference \& Exhibition on Experiential Learning'97

Ng, John dan Tan, Gilbert. 1997. Uses \& Abuses of Experiential Learning-Perspectives from a Practitioner and An Academic. Conference Proceedings Asia Pasific Conference \& Exhibition on Experiential Learning'97

Retallick, M. S. dan Steiner, Ch. 2009. A Model for Implementing a College-wide Experiential Learning Program in Higher Education, NACTA Journal, vol 53, p 2-6

Robbins, S. R. 2008. Organizational Behavior, Edisi ke-12, Jakarta:Penerbit Salemba Empat, alih bahasa Diana Angelica dkk

Simmons, S. R. 2006. "A Moving Force”:A Memoir of Experiential Learning. Journal of Natural Resources and Life Sciences Education, Vol.35, p. 132-139

Majalah SWA No.11/XXVI/26Mei-9Juni 2010, Kompas, 16 Oktober 2012 